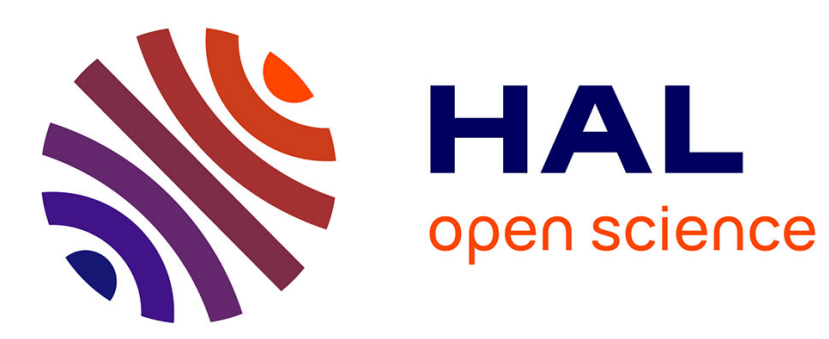

\title{
"The Destruction of New York City: A Recurrent Nightmare of American Cold War Cinema"
}

Lori Maguire

\section{To cite this version:}

Lori Maguire. "The Destruction of New York City: A Recurrent Nightmare of American Cold War Cinema". Cold War History, 2009, 9 (4), pp.513-524. 10.1080/14682740903198247 . hal-00606513

\section{HAL Id: hal-00606513 \\ https://hal.science/hal-00606513}

Submitted on 6 Jul 2011

HAL is a multi-disciplinary open access archive for the deposit and dissemination of scientific research documents, whether they are published or not. The documents may come from teaching and research institutions in France or abroad, or from public or private research centers.
L'archive ouverte pluridisciplinaire HAL, est destinée au dépôt et à la diffusion de documents scientifiques de niveau recherche, publiés ou non, émanant des établissements d'enseignement et de recherche français ou étrangers, des laboratoires publics ou privés. 
“The Destruction of New York City: A Recurrent Nightmare of American Cold War Cinema" Lori Maguire

ABSTRACT. This article examines the repeated appearance of scenes showing the
partial or complete destruction of New York City in American cinema
of the Cold War. While this theme goes across genres, it has been
particularly prevalent in science fiction films which are the focus
of this study. It begins by showing the particular reasons for this
morbid fascination and the history of such imagery in 19 th and
early 20 th century literature and cinema. The paper then analyzes
the changing presentations of destruction from the $1950 \mathrm{~s}$ to the
1980s and relates them to the dominant fears and anxieties of each
period. It concludes by taking a brief look at the continuation of
the theme in the post-Cold War period.

The destruction of New York City, in whole or in part, established itself as a frequent theme of American cinema during the Cold War, although it predates that conflict. ${ }^{1}$ It goes across genres and has appeared in films considering political questions, the impact of technology, the effect of capitalism, the nature of power, urban living and war but is especially prevalent in science fiction. There are solid reasons for this.

Science fiction, as a genre, is particularly suited to reflecting the political and social anxieties of its time especially as its main thematic focus often bears upon a grim future. Worries about current problems (as well as hopes for a better life) can be projected forward and exaggerated to show what might happen if things develop (or do not develop) in a particular way. In this manner a warning can be given or, in more optimistic times, people can 
be encouraged to progress in a certain direction. Second, it has frequently been noted that stories about alien invasion often occur at a time when the nation feels threatened and echo attitudes towards those perceived as outsiders or enemies. Furthermore, one of the main themes of science fiction concerns the relationship between humans and technology and so can be used to express important tensions relative to this bond: for example, worries about the possible misuses of scientific knowledge. Cases of this abound: anxieties about the effects of radiation in many 1950s films; the increasing dependence on and the growing powers of computers in the Terminator films or fears of genetic manipulation in a number of recent movies. For these reasons, science fiction can provide especially illuminating insights into the society of its time. ${ }^{2}$ This is particularly true of the Cold War. All of the themes mentioned earlier had a particular resonance at this period. Fears of communist assault from without or within and anxieties about the arms race, including the possibility of nuclear holocaust, all found a natural arena of expression in science fiction. And science fiction found one of its most frequent theatres in which to act out these anxieties in New York. Numerous films of the period showed that city either threatened with destruction, nearly destroyed, emptied of population or in ruins. ${ }^{3}$

Numerous other cities in the world have faced cinematic ruin but New York leads in terms of sheer volume. There are a number of reasons for this rather morbid fascination. It is, of course, the largest and most famous city in the United States and its economic capital although not its political capital which clearly differentiates it from cities like Paris and London. Furthermore, the rise of New York to giant metropolis - and more particularly that of the island of Manhattan - occurred in the $19^{\text {th }}$ century and went against the major trend of American history at that period - the westward expansion. The rise to such dominance of a city that is not a nation's political capital is something of an anomaly. New York succeeded because it was a great port: the nation's products poured out of Manhattan to Europe while 
Europe's immigrants poured into New York. For this reason, New York became the American city. Furthermore, around that port, all the things necessary for trade grew up: insurance companies, stock exchanges, businesses and banks. New York became the seat of American economic power and may have been the first city in the world in which the temples to Mammon were larger and more striking than the temples to God. ${ }^{4}$

The development of the theme of New York's destruction, which appears at a surprisingly early date, is intimately linked to this fact. In his 1838 novel, Home As Found, James Fenimore Cooper described a major fire around Wall Street. ${ }^{5}$ For him, the city was a latter day Sodom and Gomorrah and he took a certain glee in demolishing a predictable part of it: "That Exchange, which had so lately resembled a bustling temple of Mammon, was already a dark and sheeted ruin, its marble walls being cracked, defaced, tottering or fallen." ${ }^{6}$ Note how he focuses on the stock exchange which had already become an emblem of American economic power and, more particularly, of greed. To many at the time, speculation on Wall Street looked a lot like gambling and, was, therefore, rigorously condemned. Here, New York is shown as symbolic of the worst excesses of American capitalism which call forth from the author a desire to punish and allows the reader to enjoy its destruction. Ten years later, Edgar Allen Poe showed a New York ruined by an earthquake in his story "Mellonta Tauta", set in the year $2848 .^{7}$ The narrator says of the "aboriginal inhabitants":

It is related of them that they were oddly afflicted with monomania for building what was denominated "churches" - a kind of pagoda instituted for the worship of two idols that went by the names of Wealth and Fashion. ${ }^{8}$

With the earthquake, nature itself, it would seem, rebelled against this greedy, ostentatious and overly artificial city.

Which brings us to another Biblical parallel: the Tower of Babel. New Yorkers have dared to build too high and, as in the Bible, risk punishment for their arrogance. Henry James, a native of the town, was torn between wonder and horror when he returned to the new New 
York of skyscrapers which he describes in The American Scene (1907). On the one hand, he cannot help but marvel at "the most extravagant of cities, rejoicing, as with the voice of the morning, in its might, its fortune, its unsurpassable conditions". ${ }^{9}$ On the other hand, he finds violence and destructiveness within the very architecture of the city. He compares a skyscraper next to Trinity Church to "the mountain-wall that drops the Alpine avalanche". 10 In another place, he describes the city as a "monstrous organism" and says of it:

One has the sense that the monster grows and grows, flinging abroad its loose limbs even as some unmannered young giant at his "larks", and that the binding stitches must for ever fly further and faster and draw harder; the future complexity of the web, all under the sky and over the sea, becoming thus that of some colossal set of clockworks, some steel-souled machine-room of brandished arms and hammering fists and opening and closing jaws. ${ }^{11}$

New York is both monster and machine and one that keeps growing while in continual movement. It has "all the signs of the heaped industrial battlefield" - yet another violent image - and shows "the universal will to move - to move, move, move as an end in itself, an appetite at any price". ${ }^{12}$ Later, John Dos Passos named New York "the City of Destruction" and saw it as a place of personal and national testing. ${ }^{13}$ In 1949, E.B. White wrote that "by rights New York should have destroyed itself long ago, from panic or fire or rioting or failure of some vital supply circuit". ${ }^{14}$ Here, once again, we have the idea of destruction coming from the city itself.

There is, of course, a positive side to New York. It is the most famous example of the melting pot with its ethnic neighbourhoods and represents a kind of microcosm of America itself. The presence of the nation's most cherished symbol of freedom, the Statue of Liberty, with its famous inscription, also adds to New York's unique power - a symbol made perhaps even more powerful by the fact that it, and the city in which it lives, are both separated from the every day tumble of national politics. Filmmakers have been attracted for decades to its perpetual movement, its endless variety, modern architecture, economic power and its instant 
recognition. It is both quintessentially American and yet strangely alien to much of the population of that country. ${ }^{15}$ It is not surprising, therefore, to see that many of America's hopes and anxieties were given expression in and around New York.

The city has become the most popular setting for American films and, as such, many of its landmarks are instantly recognisable to people all over the world. For this reason, filmmakers often use a form of shorthand by showing a familiar landmark destroyed (or threatened with destruction) as a way of commenting on the United States. Themes that existed in literature soon appeared in cinema as well. ${ }^{16}$ The easily recognisable skyline of New York quickly became a staple shot. King Kong (Merian C. Cooper and Ernest B. Schoedsack, 1933) pioneered use of the city in American films. It is a tale of two islands, the intensely modern Manhattan (whose skyscrapers resemble, bizarrely enough, a mountain range) and the mysterious unknown island where prehistoric creatures still live, and of two monsters: the city and Kong, the giant ape worshipped by the inhabitants of the primitive island. Humans triumph over the beast for Kong is captured and taken to Manhattan. In a wonderful parody of New York's love affair with capitalism, he is displayed to the public for money but, of course, escapes and begins to destroy those very same wealthy members of society who paid to see him. Kong, of course, did not survive his encounter with Manhattan although, rather than being defeated by modern weapons, in the end, he simply lets go of the Empire State Building (a recently constructed symbol of high technology) and falls to his death. Significantly, King Kong was remade in 1976 by John Guillermin with a pronounced attack on the oil industry. This time the giant ape took refuge on the World Trade Center at the end.

Numerous other films followed King Kong and the skyline and skyscrapers of Manhattan became familiar to moviegoers. As a very visible symbol of American capitalism, their part in Cold War cinema was guaranteed, and the threat of communism to the American system could be easily dramatized by showing their destruction. ${ }^{17}$ Susan Sontag was one of the first 
to attract scholarly attention to 1950 s science fiction film in her essay "The Imagination of Disaster" where she talked about "the peculiar beauties to be found in wreaking havoc". ${ }^{18}$ Indeed, science fiction cinema often enjoys showing destruction. Partly this is cathartic but partly also it expresses a negative judgment on some aspect of American society. The fact that New York, more than any other place gets repeatedly attacked is a clear illustration of America's love/hate relationship with that city and what it stands for. After the Soviet Union exploded the atomic bomb, a Protestant preacher took some glee in announcing: "Do you know the area that is marked out for the enemy's first atomic bomb?... New York!"19

It has been estimated that between 1948 and 1962 approximately 500 feature films and shorts fell into the broad category of science fiction. Never before or since has one genre developed at such a speed in so short a time. ${ }^{20}$ Probably television played a role here as the proportion of younger people, especially adolescent males, among cinema goers increased. ${ }^{21}$ However, the subsequent decline in science fiction films in the 1960s (paradoxically at the most exciting moment of the space race) suggests that more is involved here. A quick look at the history of the period bears this out. The twin inventions of the atomic bomb and missiles and particularly their possession by the Soviet Union meant that the continental United States, which had felt fairly protected by its relative geographic isolation before, now experienced a new vulnerability. Furthermore, a number of spy cases helped to stimulate a hysterical search for communists within America by the House Un-American Activities Committee (HUAC), Joseph McCarthy and others - all of which increased this feeling of vulnerability. Added to this was the continuing spread of communism in Eastern Europe and China, the Korean War and the explosion of an atomic bomb by the USSR. All of these events received a great deal of publicity as did government efforts at civil defence: this was the age of "duck and cover" and atomic shelters. 
This situation led to an intensification of the arms race. In the 1950s, nuclear testing was done above ground and often within the U.S., in particular in the desert regions of Nevada and Utah. It became more and more clear that, in spite of government denials, the areas around these testing sites - and thus the people who inhabited them - were being contaminated by fallout. ${ }^{22}$ Because HUAC and Sen. McCarthy were searching films for evidence of disloyalty, science fiction cinema became one of the rare places where these anxieties could be expressed and the official discourse questioned. ${ }^{23}$ Not infrequently, these films were set inside New York City. ${ }^{24}$ Science fiction films of the 1950 s set a pattern of destruction that would continue long afterward.

Fears related to atomic power appeared in Captive Women of 1952 (Stuart Gilmore), set in the year 3000, which showed three rival tribes fighting for power in the ruins of New York after the atomic horror. In Five (Arch Oboler, 1951) the hero and new Adam went so far as to tell his Eve that he hated New York and was "glad it's dead". A lifeless and deserted Manhattan appeared again in The World, the Flesh and the Devil (Ranald MacDougall, 1959) where only three people have survived a nuclear holocaust, two men and a woman, and the two men stalk each other through the empty city as they fight for the woman. Atomic fears can also be found in The Beast from 20,000 Fathoms (Eugene Lourie) of 1953. Heat from an atomic bomb test in the Arctic unfreezes a dinosaur which immediately heads for Manhattan where he surfaces around Wall Street. After wreaking much havoc, he is finally trapped on the rollercoaster on Coney Island and burnt to death. This may have been the first film about a giant animal mutated by atomic power but it was certainly not the last. The following year saw two much more famous additions: that particularly Japanese nightmare, Godzilla (Ishiro Honda, 1954) and Them! (Gordon Douglas, 1954) which showed giant ants, irradiated at the New Mexico atomic test site, attacking Los Angeles. 
Fears of invasion surfaced in a number of films, particularly in the early 1950s and burning skyscrapers made frequent appearances. One of the first was Invasion USA (Alfred E. Green, 1952), a rather bizarre film shot in seven days. It details the invasion of America by an unidentified enemy whose accents sound suspiciously Russian. The attacks occur in a number of places, notably New York, where skyscrapers get bombed. At the end of the film, however, the invasion is revealed to be an illusion induced by some form of mass hypnosis. It is, therefore, not too late to save the nation and the message here seems to be that all citizens must be prepared and vigilant against communism - very much in keeping with the McCarthyite discourse of the period. However, perhaps because it was made so quickly, the message frequently gets a bit muddled. The hero, for example, is cynical and always on the look out for his own advantage. ${ }^{25}$ The publicity for the film was as bizarre as the film itself. The trailer gleefully announces "See New York disappear" while publicity shots showed beautiful women in bathing suits posing next to models of burnt out skyscrapers. The whole thing seemed to say that Armageddon would be fun especially for men. ${ }^{26}$ Invasion USA launched a whole series of atomic disaster films and New York was far from being the only ravaged city. Byron Haskin's 1953 version of The War of the Worlds, based on H.G. Wells's novel, gives a fairly realistic vision of an invasion, achieved by the use of archival images from the Second World War. It takes place, however, in Los Angeles. Many of Washington D.C.'s monuments were destroyed in Earth vs. Flying Saucers (Fred Sears, 1956) while small town America got quietly invaded in Invasion of the Body Snatchers (Don Siegel, 1956).

After this, there was a brief reprieve for New York City until the launching of Sputnik in 1956 provoked a new wave of destruction films. Sputnik may have panicked the American government but Hollywood saw it as an opportunity. It convinced movie makers to invest in movies that had a similar theme. According to some estimates, as many as 43 such projects were announced on the day after Sputnik's lift-off. ${ }^{27}$ It was even once mockingly suggested 
that Sputnik "should be in for 10 per cent". ${ }^{28} 1957$ saw, among other things, Deadly Mantis, in which a giant killer preying mantis defrosts in the Arctic and heads to Manhattan and The Giant Claw in which a giant bird devastated the Big Apple. In 1958's Colossus of New York, a killer robot went on a rampage. Finally, Robot Attack USA (1960) ends with missile attacks on Manhattan.

The number of American science fiction films declined in the 1960s. To a large extent this was because the genre was failing to renew itself and people were growing tired of formulaic, repetitive movies. But, as many scholars have pointed out, current events also played a role. After the Cuban missile crisis of 1962, worries about Armageddon declined, as did, after the Test Ban Treaty of 1963, anxieties about radiation. The policy of détente also reassured people and convinced them that nuclear war was unlikely. Much of the nation's attention was now focused on the Vietnam War and on inner turmoil: the civil rights movements, student protests, women's liberation, etc. These would all find expression in the science fiction of the time. The space race also became a national priority and inspired many stories. ${ }^{29}$ Science fiction films exhibited a new social consciousness, which was very much in keeping with the spirit of the time (at least on the left). Present day fears were still projected into the future with often devastating effects but the nature of these anxieties was more varied. ${ }^{30}$ Interestingly enough, while images of the skyscrapers continued, prominent use was made of another, even better known New York landmark, the Statue of Liberty.

Representative as it is of the United States itself, and more particularly, of its system of government and of its identity as a nation of immigrants, the statue could become a potent commentary. Lady Liberty had appeared in films before the Cold War (most notably in Hitchcock's 1942 film Saboteur where the finale takes place there) but its obvious symbolism made it a favourite backdrop in the Cold War. Going a step further, showing its destruction could serve as a tool to make important observations about America and its values. 
The most famous example of this is undoubtedly in Franklin J. Schaffner's Planet of the Apes (1968) loosely based on a 1963 novel by the French writer Pierre Boulle. The plot concerns four astronauts who, leaving earth in 1972, arrive on a planet where apes are the evolved and dominant species while humans are in a primitive stage of development before speech. Only at the end does the one remaining astronaut, George Taylor, enter the so-called "Forbidden Zone" to find the wreckage of the Statue of Liberty. To his shock and horror he realizes that he has not journeyed through space but through time and that, at some point, humanity destroyed itself. Traditionally, of course, the Statue of Liberty functions as the symbol of an ideal America: land of freedom and of refuge. ${ }^{31}$ So the film is making an ironic comment on this. Taylor's last words hammer home the point:

Oh my God! I'm back! I'm home. All the time it was... We finally really did it. You maniacs! You blew it up! God damn you! God damn you all to hell! ${ }^{32}$

Note how he refuses the idea of an exterior enemy destroying America for "we finally really did it." Here is a fundamental difference with earlier films which saw destruction coming from outside. Taylor gives us a highly critical viewpoint on the Cold War and the arms race. In the four sequels to the film we learn more about the reasons for the obliteration of human society (although the origins of the original nuclear disaster are never clearly explained). We even witness the final destruction of Earth itself at the end of the second film. Ostensibly about space exploration, people continually enter space but do not reach any place but Earth. Frozen in place, all travel is done through time. Central to all these movies is human destructiveness and nuclear apocalypse (which has either happened or is about to happen). Beneath the Planet of the Apes (Ted Post, 1970) even goes so far as to parody the arms race and government propaganda about nuclear weapons by showing a future humanity that actually worships the bomb as God - in a now underground St Patrick's cathedral. The films reflect a number of other anxieties in late 1960s and early 1970s America, notably with regard 
to racial conflict and the Vietnam War, as well as fears of totalitarianism and fascist takeover. $^{33}$

The Statue is used to similar effect in John Carpenter's Escape from New York (1981) which shows a devastated Manhattan where the entire island had been turned into the nation's one maximum-security prison. As the introduction to the film explains:

A 50-foot containment wall is erected along the New Jersey shoreline, across the Harlem river, and down along the Brooklyn shoreline. It completely surrounds Manhattan island. All bridges and waterways are mined. The United States Police Force, like an army, is encamped around the island. There are no guards inside the prison: only prisoners and the worlds they have made. The rules are simple. Once you go in, you don't come out. ${ }^{34}$

The political aspect of the film is clear from its first scenes which show two prisoners trying to escape Manhattan in a boat. They are ordered back by the helicopter that patrols the waters around the island and when they do not immediately turn around, they are shot in cold blood. The scene then switches to the Statue of Liberty where a sign reads "Liberty Island Security Control". The commentary on a potential loss of liberty from an obsession with repressing crime seems obvious. Too much of a preoccupation with security, Carpenter's film seems to say, can lead to a loss of all freedom. The plot concerns Snake Blissken, who is forced to enter Manhattan to rescue the president whose plane has crashed there after a terrorist attack. Blissken travels through the ruined streets of the city trying to find the gang leader who has kidnapped the president. No one in the film is really likeable: not the gang leader, not the president and especially not the officials who have forced Blissken to rescue him. At the end, Blissken, in a scene reminiscent of High Noon, walks away in disgust.

Interestingly enough, the very absence of a recognisable landmark can also provide a commentary. Soylent Green (Richard Fleischer, 1973) shows New York in the year 2022, victim of pollution, overpopulation, and corporate greed. The film obviously reflects anxieties related to urban decay but has an anti-capitalist subtext linked to its portrayal of the allpowerful Soylent Corporation that connects it to the Cold War. In this nightmare world, real 
food is practically non-existent and synthetic rations are provided by the Soylent Corporation, whose latest product is called Soylent green. At the end, the hero discovers that Soylent green is made from human corpses - capitalist exploitation has run so far out of control that it has become cannibalism. New York is clearly mentioned as the setting at the beginning of the film but none of the usual landmarks are visible. The absence of colour, landmarks and, indeed, of anything singular about the city - other than its greyness and overpopulation reinforces the point of the film.

Along with capitalism, the American system of government gets criticised in Soylent Green and in other science fiction films of the period. 1979's Meteor has a small meteorite destroying part of the city. In keeping with the post-Watergate spirit of the times, the United States government is dishonest, denying the existence of secret weapons aimed at Russia which they have placed in space (and which are the only thing that can destroy the meteorite and save the earth) - although, to be fair, the Russians are doing the same thing. There is also yet another delusional, Cold War obsessed general. 1984's C.H.U.D. (Douglas Cheek) shows the U.S. government illegally transporting toxic waste through subway tunnels. Exposure to this has transformed people into monsters who feed on the homeless.

But, in general, in the 1980s, with the Cold War heating up after the Soviet invasion of Afghanistan and the election of Ronald Reagan, and the feeling of vulnerability created by the Iran hostage crisis, it became more and more common to show exterior threats to New York. Already in 1980, Superman II (Richard Donner and Richard Lester) showed space aliens destroying Times Square. 1982's Q-The Winged Serpent had the Aztec flying serpent god, Quexcoatl, nesting on the top of the Chrysler Building and nourishing himself on the blood of New Yorkers. As the decade progressed, though, parody appeared in films. The two Ghostbusters films (Ivan Reitman, 1984 and 1989) took a comic view of the apocalypse which, of course, threatened to occur in New York. In a spoof of giant monster films, a huge 
Pillsbury Doughboy marches through city streets bringing Armageddon with it while, in the second film, the Statue of Liberty comes to life to save the city. 1990's Gremlins II (Joe Dante) presents the annoying little creatures as a comic threat to Manhattan (they even get to sing "New York, New York") while the tiny, adorable mogwai, Gizmo, plays Rambo.

During the Cold War, the destruction of New York City appeared repeatedly. In the 1950s the devastation of American cities (but especially Manhattan) by alien invaders or by giant atomically mutated animals represented fears of nuclear war or of nuclear testing. These films are often seen as allegories on the Cold War, ${ }^{35}$ but a very real tension often exists in them: the military is needed to kill the monster but atomic experiments are usually responsible for the threat in the first place. In the 1960s and 1970s the tone of the films became increasingly ironic and there was often a commentary on social questions. In the 1980s fantasy and humour appeared more frequently although some films did present serious threats to New York or other American cities. The over-populated and ultra-modern island of Manhattan has appeared as a metaphor for humanity's conquest of nature - and its consequences. Its familiar landmarks, economic power and very particular beauty have made it a magnet to film directors. Its iconic status as the American city has also given it a special power and attraction. New York proudly proclaims itself as the capital of the world and in a certain sense this is true. The destruction of New York reflects America's insecurities both about herself and about her place in the world. But there has also been a certain pleasure taken in this devastation; a judgment that is passed on the city and what it stands for - New York's destruction is often seen as in some way deserved because of its sins.

Interestingly enough, the end of the Cold War did not bring a reprieve for Manhattan and, indeed, the number of destruction scenes actually increased. ${ }^{36}$ By the end of the 1990s, films were showing familiar places exploding all over New York. 1995's Independence Day (Roland Emmerich) imagined an alien invasion of the world, and, more particularly, of the 
United States. Although the Americans triumph in the end, the film shows the annihilation, one by one, of the greatest icons of American power and prestige. The pace of devastation continued over the next few years. In 1997's Deep Impact (Mimi Leder), the world is threatened by a comet which, among other disasters, causes a tidal wave to hit New York, destroying the Brooklyn Bridge and much of Manhattan. In 1998's Armageddon (Michael Bay), meteorites menace the earth and a destructive shower of them falls on Manhattan. In the same year Godzilla returned to the big screen - this time attacking New York. The tide did not diminish in the following years. Whether consciously or not, Osama bin Laden and the terrorists of 11 September 2001 gave reality to one of the most frequent representations of American anxiety. If unconscious, the attacks show to what extent Hollywood has penetrated the unconscious even of those who most hate everything it stands for. There seems to have been no particular goal to the September $11^{\text {th }}$ attacks except to hurt and to express hatred. It is certainly difficult to see how they could have forwarded any political goals that al Qaeda may have (and whether they have any is a subject of much debate). Or perhaps they simply wanted to tell America that her anxieties were real.

\footnotetext{
${ }^{1}$ I would like to thank Arnaud Regnauld and Henri Zuber for their help and advice.

${ }^{2}$ Numerous studies of science fiction cinema exist. To name but a few: Kuhn, ed, Alien Zone; Kuhn, ed, Alien Zone II; Sobchak, The Limits of Infinity; Seed, American Science Fiction and the Cold War and Brosnan, Future Tense; Bartholomew, "Science Fiction Films"; Peary, ed. Omni's Screen Flights/Screen Fantasies. There are many others that there is not the space to list here.

${ }^{3}$ A number of films outside the science fiction genre also played with this theme, such as Fail Safe (Sidney Lumet, 1964). Others showed New York as a crime-ridden wreck, like Mean Streets (Martin Scorsese, 1973), Taxi Driver (Martin Scorsese, 1976) and The Warriors (Walter Hill, 1979). 1981's Fort Apache, the Bronx (Daniel Petrie, 1981) showed a corrupt and racist police force battling even worse criminals and Nighthawks (Bruce Malmuth, 1981) concerned the arrival of Europe's most famous terrorist in the city.

${ }^{4}$ New York, of course, was also faulted for its seediness: bars, prostitution, etc. For histories of New York, see Lankevich, American Metropolis?; Moorhouse, Imperial City; Kaspi, ed. New York, 1940-1945; Muhlstein. Manhattan to name but a few

${ }^{5}$ Such a fire did, in fact, occur in 1835. Fraser, Wall Street, 43

${ }^{6}$ James Fenimore Cooper, Home As Found, 108-9

${ }^{7}$ The title means "things of the future" in Greek which already links it to science fiction.

${ }^{8}$ Poe "Mellonta Tauta", 381
} 
${ }^{9}$ Henry James, The American Scene, 74

${ }^{10}$ Ibid., 83

${ }^{11}$ Ibid., 75

${ }^{12}$ Ibid., 84

${ }^{13}$ John Dos Passos, The Best Times, 86. See also O'Connell, Remarkable, Unspeakable New York, 135

${ }^{14}$ E.B. White, Here is New York (New York: Harper, 1949) pp. 24-5

${ }^{15}$ Mulvey and Simmons in New York: City as Text, 1 make the point that since New York is, in a sense, between Europe and America, facing towards both, it "can represent both a spiritual antithesis to the middle America that would repudiate it and an American epitome to the rest of the world that would embrace or repudiate it." Ric Burns wrote in the companion volume to the PBS history of New York: "To many foreigners its represents America; to many Americans, it represents all that is foreign." Burns and Sandars, New York, xiii.

${ }^{16}$ As far as I can tell, the first film to destroy New York was The Battle Cry of Peace (Wilfrid North, 1915), now lost. It details the city's invasion by an unidentified enemy that look German. It was generally seen as Allied propaganda. See The New York Times' review, 7 August 1915. New York was attacked again in a forgotten pacifist film of 1933, Men Must Fight (Edgar Selwyn)

${ }^{17}$ Wollen, "Delirious Projections", 25 sees some parallels between the skyscraper, and film, which developed at the same time.

${ }^{18}$ Sontag, "The Imagination of Disaster" 213. See also Murphy, "Monster Movies".

${ }^{19}$ Quoted in Whitfield, The Culture of the Cold War 77. Barry Keith Grant wrote: "We eagerly await the climactic tidal wave that will sweep over New York and its landmarks of western civilisation." "Sensuous Elaboration"", 22.

${ }^{20}$ For more on this see Evans, Celluloid Mushroom Clouds, 75 and Michaels, The American Movies Reference Book.

${ }^{21}$ Although Barclay, in his study of Viewing Tastes of Adolescents in Cinema and Television, 18, found that the genre was not particularly appreciated by British adolescent boys with 39 per cent listing science fiction as their least favourite type of film.

${ }^{22}$ For more on this, see Evans. Also Perrine, Film and the Nuclear Age and Boyer, By the Bomb's Early Light.

${ }^{23}$ See, for example, Weart, Nuclear Fear, 194

${ }^{24}$ As Sandars observes in Celluloid Skyline, 387-8: "How better to convey the end of the world than to show the destruction of its best-known place... In the nuclear era, the greatest symbol of civil society was inevitably the greatest possible target, whose annihilation would provide the most wrenching symbol of atomic nightmare."

For more information on the film and examples of publicity shots and posters see http://www.conelrad.com/features/invasionusa/index.html. Accessed 15/01/03

${ }^{26}$ The trailer can be found at http://www.youtube.com/watch? $\mathrm{v}=\mathrm{cNZaMm5q}$ BA. Accessed 20/02/2009

${ }^{27}$ See Doherty, Teenagers and Teenpics, 152.

${ }^{28}$ Ibid.

${ }^{29}$ And even some that belong to the domain of fantasy like the television series I Dream of Jeannie.

${ }^{30}$ See Dean, "Between 2001 and Star Wars". Fried's The Russians Are Coming! shows the decline of patriotic displays at the end of the 1950s. The following decade saw increasing cynicism about American institutions and values caused by the revelation of racial inequality through the civil rights movement and disillusionment with the Vietnam War. Watergate, of course, further increased cynicism in the 1970s.

${ }^{31}$ The inscription on the Statue, by Emma Lazarus, reads: "Give me your tired, your poor,/ Your huddled masses yearning to breathe free,/The wretched refuse of your teeming shore./Send these, the homeless, tempest-tossed to me./ I lift my lamp beside the golden door."

${ }^{32}$ The script is available online at http://pota.goatley.com/scripts/pota_finalshoot2.pdf. Accessed 25/02/2009. Interestingly enough, only the first words "My God!" can be found in the shooting script. The rest seems to have been added during filming.

${ }^{33}$ For more on this see Greene, Planet of the Apes.

${ }^{34}$ The script can be found at http://www.imsdb.com/scripts/Escape-From-New-York.html Accessed 25/2/2009

${ }^{35}$ See, for example, Biskind, Seeing is Believing or Sayre, Running Time.

${ }^{36}$ Stephen Keane comments in Disaster Cinema, 101, that "in 1998 watching New York getting destroyed became standard fare."

\section{References}

Barclay, J. B. Viewing Tastes of Adolescents in Cinema and Television. Glasgow: Scottish Educational Association, 1961 
Bartholomew, David. "Science Fiction Films." In A Political Companion to American Film, edited by Gary Crowdus. Chicago: Lakeview Press, 1994.

Biskind, Peter. Seeing is Believing. New York: Pantheon, 1983

Boyer, Paul. By the Bomb's Early Light: American Thought and Culture at the Dawn of the Atomic Age. New York: Pantheon Books, 1985

Brosnan, John. Future Tense: The Cinema of Science Fiction. London: Macdonald \& Jones, 1978

Burns, Ric and James Sandars. New York: An Illustrated History. New York: Knopf, 1999

Cooper, James Fenimore. Home As Found (New York: Putnam, 1896 edition)

Dean, Joan. "Between 2001 and Star Wars." The Journal of Popular Film and Television, 7, no. 1 (1978) 32-41.

Doherty, Thomas. Teenagers and Teenpics: The Juvenalization of American Movies in the 1950s. Boston: Unwin Hyman, 1988

Dos Passos, John. The Best Times. New York: New American Library, 1966.

Evans, Joyce. Celluloid Mushroom Clouds: Hollywood and the Atomic Bomb. Boulder, Col:

Westview Press, 1998

Fraser, Steve. Wall Street: A Cultural History. London: Faber \& Faber, 2005

Fried, Richard. The Russians Are Coming! The Russians Are Coming: Pageantry and Patriotism in Cold War America. Oxford: Oxford University Press, 1998

Grant, Barry Keith. "Sensuous Elaboration' Reason and the Visible in the Science Fiction Film.” In Alien Zone II, edited by Annette Kuhn. London: Verso, 1999.

Greene, Eric. Planet of the Apes as American Myth: Race, Politics and Popular Culture. Jefferson, N.C.: McFarland, 1996

James, Henry. The American Scene. Garden City: Scribner's, 1946.

Kaspi, André, ed. New York, 1940-1945: Terre promise et corne d'abondance. Paris, Edition Autrement, 1995

Keane, Stephen. Disaster Cinema: The Cinema of Catastrophe. London: Wallflower, 2001

Kuhn, Annette, ed. Alien Zone. London: Verso, 1990

Lankevich, George. American Metropolis? A History of New York City. New York: New York University Press, 1998

Michaels, Paul. The American Movies Reference Book: The Sound Era. Englewood Cliffs: Prentice Hall, 1969

Moorhouse, Geoffrey. Imperial City: the Rise and Rise of New York. London: Hodder \& Stoughton, 1989

Muhlstein, Anka. Manhattan : la fabuleuse histoire de New York des Indiens à l'an 2000. Paris : Grasset, 1986

Mulvey, Christopher and John Simmons, eds. New York: City as Text. Basingstoke: Macmillan, 1989

Murphy, Brian. "Monster Movies: They Came from beneath the Fifties." Journal of Popular Film, 1, no. 1 (1972) 31-44

O'Connell, Shaun. Remarkable, Unspeakable New York: A Literary History. Boston: Beacon Press, 1995.

Peary, Danny, ed. Omni's Screen Flights/Screen Fantasies: The Future According to Science Fiction Cinema. Garden City, New York: Doubleday, 1984.

Perrine, Toni. Film and the Nuclear Age: Representing Cultural Anxiety. New York: Garland, 1998

Poe, Edgar Allen. "Mellonta Tauta." In Complete Stories and Poems of Edgar Allan Poe. New York: Doubleday, 1966. 
Sandars, James. Celluloid Skyline: New York and the Movies. London: Bloomsbury, 2001 Sayre, Nora. Running Time. New York: Dial Press, 1982

Seed, David. American Science Fiction and the Cold War. Edinburgh: Edinburgh University Press, 1999.

Sobchak, Vivian. The Limits of Infinity. London: A.S. Barnes, 1980

Sontag, Susan "The Imagination of Disaster." In Against Interpretation and Other Essays. New York: Farrar, Straus \& Giroux, 1966

Weart, Spencer. Nuclear Fear: A History of Images. Cambridge, Mass: Harvard University Press, 1988

White, E.B. Here is New York. New York: Harper, 1949

Whitfield, Stephen. The Culture of the Cold War. Baltimore: Johns Hopkins, 1991

Wollen, Peter. "Delirious Projections." Sight and Sound, 2, no. 4 (1992) 24-7. 